UDC $314.4 ; 316.6(470.12)$

DOI: $10.21668 /$ health.risk/2018.2.05.eng

\title{
BEHAVIORAL FACTORS WHICH CAN INFLUENCE PRESERVATION OF YOUNG PEOPLE'S HEALTH
}

\section{M.A. Gruzdeva, A.V. Korolenko}

Vologda Research Center of the Russian Academy of Sciences, 56A Gorky Str., Vologda, 160014, Russian Federation

Young people play a most important role in society's life as they possess significant intellectual, creative, labor and reproductive potential. However, this potential might not find its implementation in reality due to both inevitable reduction in number of people belonging to this population category and deteriorating quality of it. And a key issue here is preservation of young people's health. Contemporary young people have poorer health than the previous generations and we can observe a so called "social ill health funnel". There is another acute issue related to demographic losses caused by mortality among young people; they die due to outer causes, circulatory system diseases, malignant neoplasms, and digestive organs diseases, and this mortality is to a great extent determined by behavioral factors. The paper dwells on the analysis of basic selfpreservation behavioral parameters determined via a sociological questioning performed among people living in Vologda region. We revealed that those respondents who were younger than 30 tended to evaluate their health as being "good" and "very good" more frequently than older ones; chronic diseases were significantly less frequent among people from younger age groups. We detected that $74 \%$ young people pursued certain health-preservation practices while the remaining $26 \%$ did nothing to preserve their health. Young people explain their striving for health

preservation mostly by a desire to have healthy children, to look well, and to achieve their life goals. They don't often visit a doctor with prophylaxis in mind; they tend to do sports. But still, there are young people who indulge in self-destructing behavior. Young people drink low alcohol beverages more often than people from older age groups. $36 \%$ of them smoke but $51 \%$ of smokers wish to give this bad habit up. Fast food is also more popular with young people: $39 \%$ eat it several times a week. And sometimes it is a desire to overcome a stress that makes young people smoke, drink alcohol or eat unhealthy food. region.

Key words: young people, health, behavioral factors, self-preserving behavior, healthy lifestyle, Vologda

Young people as a peculiar socialdemographic group possess great intellectual and creative potential; they are generally in good shape and play a key role in reproduction thus being a great reserve for labor resources replenishment.

Over 2000-2016 a number of young people aged 15-29 decreased both in Russia as a whole and in Vologda region. The number of people in this population category went down by $17 \%$ in the country in general (to 27,588 thousand people), and its share in the overall population structure fell by $4 \%$ (to 19\%). The decrease in young people's number and specific weight was even greater in the region and reached $27 \%$ (to 206 thousand people) and $4 \%$ (to $17 \%$ ) correspondingly [1]. So, a quantita-

(C) Gruzdeva M.A., Korolenko A.V., 2018

Mariya A. Gruzdeva - Candidate of Economic Sciences; Head of Laboratory for Research on Managerial Issues in Social Sphere, senior researcher at Department for Research on Population Lifestyle and Living Standards (e-mail: mariya antonovarsa@mail.ru; tel.: +7 (8172) 59-78-10 (ext. 300)).

Aleksandra V. Korolenko - junior researcher at Laboratory for Research on Managerial Issues in Social Sphere and Department for Research on Population Lifestyle and Living Standards (e-mail; coretra@yandex.ru; tel.: +7 (8172) 59-78-10 (ext. 305)). 
tive potential of young generations is gradually running out. According to the Rosstat mean predictive variant, this trend is likely to continue in the next two decades. As a results, a number of people aged 15-29 in Russia will decrease by 379.6 thousand by 2035 in comparison with 2016 and will amount to 27,208.4 thousand people [2].

Better quality of this population category is a condition for overcoming negative trends in dynamics of young generations number. Young people's health is the most important qualitative characteristic of young people due to its being a vital indicator of the future labor, economic, and reproductive potential of any society [3]. Health is a kind of a "superstructure" for formation and development of other components in human potential. However, loss of youth's health potential is a serious problem which our society faces in the $21 \mathrm{st}$ century. As N.M. Rimashevskaya states, in Russia we can observe a so called "social ill health funnel" when each subsequent generation has weaker health than the previous one $[4,5]$, that is, contemporary young people have less health resources than their parents.

But still, there are mostly positive trends in statistical health indicators. Since 2006, when active social and demographic policy was first implemented in Russia, and up to 2015 life expectancy (LE) in Vologda region grew significantly, including young people aged 15-29 (by 5 years for males, and by 3 years, for females; Figure $1)^{1}$. However, a significant discrepancy in it between males and females still exists. Thus, LE for young males aged 15-29 is 12 years shorter than for females from the same age category.

A parameter showing "lost years of potential life" (LYPL) is a leading population health indicator; it shows a number of years which population failed to live to reach a certain standard level $[8,9]$.

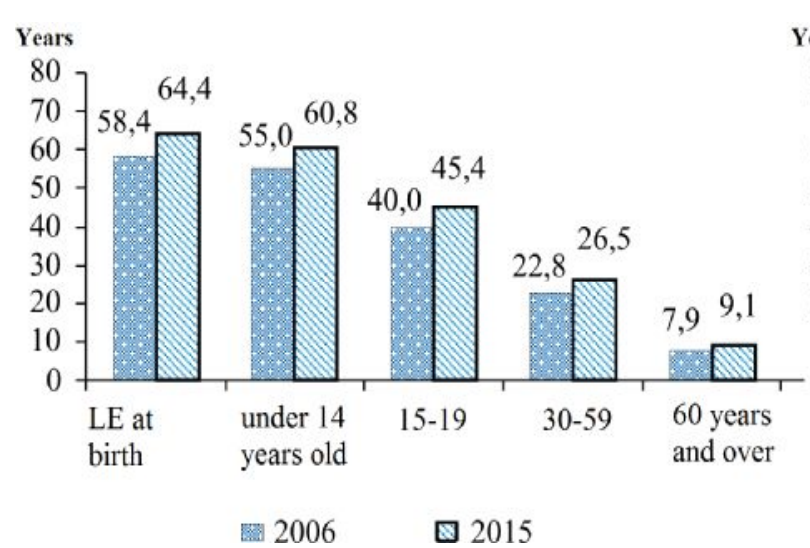

$a$

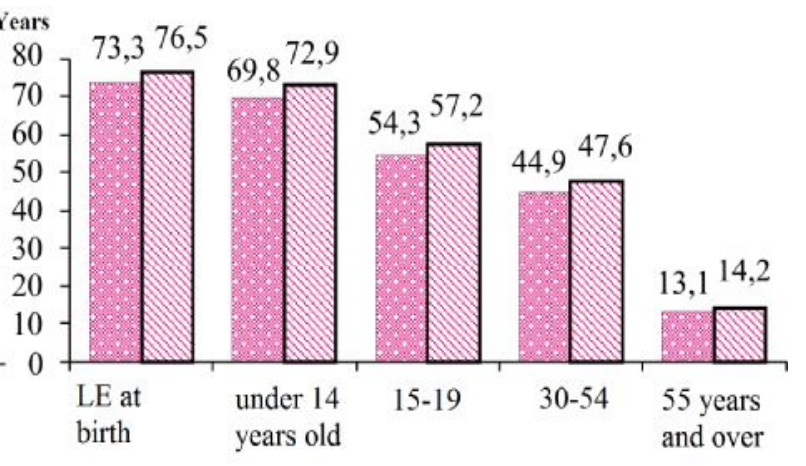

2006 ⑳15

Figure 1. LE for male (a) and female (b) populations in Vologda region for various age groups in 2006 and 2015 (years). Sources: calculated by the authors as per: [6, 7].

The choice of the category of 15-29 years in the analysis of statistical indicators of health is due to the peculiarities of calculating the LE tables for 5-year age groups. 
Table 1

LYPL due to population mortality in Vologda region as per age and sex groups and death causes, 2015. (person-years per 100,000 people according to age and sex)

\begin{tabular}{|l|c|c|c|c||c|c|c|c|}
\hline \multirow{2}{*}{\multicolumn{1}{|c|}{ Death causes }} & \multicolumn{7}{|c|}{ Males } & \multicolumn{5}{c|}{ Agemales } \\
\cline { 2 - 9 } & Under 14 & $15-29$ & $30-59$ & $60-64$ & до 14 & $15-29$ & $30-54$ & $55-74$ \\
\hline All the causes & $\mathbf{7 2 4 4 , 1}$ & $\mathbf{8 6 6 9 , 4}$ & $\mathbf{2 0 2 8 9 , 6}$ & $\mathbf{1 1 3 9 5 , 9}$ & $\mathbf{4 3 7 6 , 8}$ & $\mathbf{3 3 1 6 , 4}$ & $\mathbf{9 2 0 9 , 6}$ & $\mathbf{1 3 6 4 6 , 8}$ \\
\hline $\begin{array}{l}\text { Circulatory system dis- } \\
\text { eases }\end{array}$ & 472,4 & 737,5 & 6213,8 & 5812,4 & 354,0 & 308,3 & 3605,0 & 2337,9 \\
\hline Neoplasms & 321,5 & 606,6 & 1970,5 & 2553,9 & 128,8 & 592,3 & 3091,1 & 1202,1 \\
\hline Outer causes & 2981,8 & $\mathbf{5 6 7 9 , 8}$ & 5981,6 & 1012,8 & $\mathbf{6 8 3 , 4}$ & $\mathbf{1 4 9 7 , 8}$ & 2212,4 & 273,6 \\
\hline $\begin{array}{l}\text { Digestive organs dis- } \\
\text { eases }\end{array}$ & 399,3 & 578,9 & 3259,6 & 933,5 & 215,3 & 186,1 & 2259,5 & 456,0 \\
\hline $\begin{array}{l}\text { Respiratory organs dis- } \\
\text { eases }\end{array}$ & 222,2 & 385,3 & 891,2 & 475,6 & 71,8 & 0,0 & 456,8 & 107,8 \\
\hline All the causes & 177,2 & 114,3 & 494,8 & 88,1 & 143,6 & 340,3 & 266,6 & 24,9 \\
\hline
\end{tabular}

Note: *as a discrepancy in life expectancy for males and females is significant both in the country as a whole and in the region (more than 10 years), we applied a different age standard a person should live to for men and women, 65 and 75 years correspondingly. Source: calculated by the authors as per: $[6,7]$

We analyzed demographic losses via calculating LYPL and revealed that outer causes made the greatest contribution into losses due to untimely death among population aged 15-29. They accounted for $5,679.8$ person-years per 100,000 people or $66 \%$ for males; and for $1,497.8$ personyears per 100,000 people or $45 \%$ for females (table 1). But at the same time we should note that there are high LYPL losses due to circulatory system diseases (9\% for males and females); malignant neoplasms ( $7 \%$ for males, $18 \%$ for females); digestive organs diseases $(7 \%$ for males, and $6 \%$ for females).

In this respect, research on specific health determinates becomes truly vital as it helps to reveal possibilities how to manage them, to eliminate influences exerted by adverse factors, and to enhance positive effects.

Yu.P. Lisitsyin, a Russian expert in social hygiene, spotted out such key health factors as a life style and social-economic conditions, quality of the environment, genetic and biological factors, and an existing public health care system, basing on a model created by the World Health Organization
(WHO) experts [10]. And the first factor here makes the greatest contribution into one's health (50-55\%). Other experts also confirm this conclusion. Thus, foreign experts in the sphere of public health and health care note that such preventable behavioral factors as tobacco smoking, lack of physical activity, irrational nutrition, and alcohol abuse, are now basic reasons causing most widely spread non-infectious diseases (cardiovascular diseases, cancer, chronic respiratory diseases, and pancreatic diabetes) [11-13]. It is these factors that determine four basic physiological changes: high blood pressure, excessive body weight (obesity), hyperglycemia, and hyperlipidemia [14].

So, factors related to a life style play the leading role in formation of one's health, and this fact calls for more profound research on population behavior which helps to preserve it and there are such concepts here as "self-preserving behavior" and "healthy life style". Self-preserving behavior is a system of needs, attitudes, motives, and actions which an individual pursues in striving for his or her health preservation and improvement. Self- 
preserving behavior can be both negatively and positively oriented; in the first case in is called "self-destructing behavior" [15]. Healthy life-style is closely connected with the positive side of self-preservation. Primarily it means giving bad habits up, rational and balanced nutrition, physical and medical activity, reasonable work and rest regime, and mental well-being [16]. Our research goal was to examine youth's selfpreserving behavior and reveal its peculiarities in comparison with other age groups.

Our research goal - study of selfpreserving behavior of young people and the identification of its specific characteristics in comparison with other age groups.

Data and methods. Sociologic research results allow to analyze peculiarities of self-preserving behavior at an individual level. Sociological data collected at a certain stage of sociological monitoring over physical health of population in Vologda region were used as an information ground in this work. This monitoring stage was performed in 2016 by Vologda Scientific Center of the Russian Academy of Science via questioning. The first questioning took place in 2002 and has been performed each two years since then in Vologda, Cherepovets, and in eight municipal districts in Vologda region. Sampling volume is 1,500 respondents aged 18 and older ${ }^{2}$; each sam- pling is multi-stage and quota. Sampling error doesn't exceed 3\%. Empirical data are usually collected via questioning; social workers visit people in their apartments, hand questionnaires out and then collect them. All the collected information is then technically processed with SPSS and Excel software.

Results and discussion. Health occupies the leading place in key values of the region population. Young people gave such answers a bit less frequently than people from other age groups: $70 \%$ against $75 \%$ among respondents aged $30-55(60)^{3}$ and $89 \%$ among retired people (criterion $\chi^{2}$ $=46.343$ with $\mathrm{p}<0.001$ ).

A desire to live a long life is vital for self-preserving practices implementation. People younger than 30 have the greatest desire to live longer than 90 years; that is, they have a motivation to take care of their health. It fits well with the fact that $90 \%$ young people state they bear their own personal responsibility for their health, and only $29 \%$ believe that medical staff are responsible for it. People from older age groups give quite different answers and they more frequently think that medical workers are responsible for their health: $33 \%$ of people aged $30-55$ (60) and $45 \%$ of retired people adhere to such an opinion (criterion $\chi^{2}=24.350$ at $p<0.001$ ).

In spite of the overall deterioration of

\footnotetext{
${ }^{2}$ Representativeness of received sociological information about methods of multistage regionalized sample with quota selection of units of observation. At the first stage, in order to ensure homogeneity of the sample population, the allocation of typical economic regions within the Vologda region was carried out. Two cities (Vologda and Cherepovets) and eight municipal districts with different levels of social and economic development have entered the zoning structure: three districts with high and medium development level (Sheksninsky, Gryazovetsky, Veliky Ustyug municipal districts), three districts with medium (Tarnogsky, Kiril-Lovsky, Babaevsky) and two with a low level of development (Nikolsky, Vozhegodsky). (Except for Tarnogsky, since the administrative center of the district is Tarnogsky Gorodok - is a village). For the cities of Vologda and Cherepovets, zoning on city (electoral) districts was additionally carried out. Further, the sample set is broken up in accordance with the quotas for the sex and age composition of the population. At the last stage to participate in the voice process - the selection of respondents was conducted by random route method.

${ }^{3}$ Age groups: from 18 to 30 years - young people, from 30 to 55 (60) - adult population, 55 years and older (60) - pensioners, where 55 years old - retirement age of women, 60 years old - retirement age for men.
} 
contemporary youth's health against previous generations, young people, as a rule, tend to be healthier than people from older age groups and retired people as they haven't yet accumulated "health problems" including those caused by their own behavior. Therefore, there is a regularity traced in all the responses collected during questionings: young people more frequently assess their health as good and very good (about 70\%) while people aged 30- 55 (60) give such answers only in $40 \%$ cases, and retired people, in $12 \%$ cases only $\left(\chi^{2}=\right.$ 279.915 at $\mathrm{p}<0.001)$. 13\% of young people stated they had various chronic diseases while this parameter was substantially higher among people from other age categories $(18 \%$ of respondents aged 30$55(60)$, and $39 \%$ of retired people; $\chi^{2}=$ 86.473 at $\mathrm{p}<0.001)$.

There are several motives that make population in the region to preserve and improve their health; they are a desire to feel oneself well (46\% responses), a desire to look well (32\%), and a wish to avoid causing any inconvenience for one's family (32\%) (Table 2). Young people also stress their desire to look well and to be liked by others $\left(42 \% ; \chi^{2}=15.669\right.$ at $\left.p<0.001\right)$. Young years are a great time for active studies and building one's career, and it is confirmed by motives that make young people care about their health. Young people state that they need good health to achieve their goals in life, work, and studies, more frequently than people from other age groups $\left(15 \% ; \chi^{2}=30.524\right.$ at $p<$ $0.001)$. A desire to have healthy children is the most popular answer to a question about reasons for taking care of one's health among young people $\left(47 \% ; \chi^{2}=\right.$ 241.719 at $p<0.001)$.

A more profound analysis of $\mathrm{Vo}$ logda population lifestyle revealed that only $5 \%$ of people living in the region didn't have any destructive habits in their everyday life or self-preserving behavior, and their lifestyle could be considered truly healthy. Accordingly, 95\% people had at least one destructive component in their behavior [17, 18]. The questioning revealed that $26 \%$ young people didn't take any measures to preserve and

Table 2

Distribution of answers to the question "What makes you take care of your health?"

(in \%; ranked as per answers given by young people)

\begin{tabular}{|c|c|c|c|c|c|}
\hline \multirow[b]{2}{*}{ Motives } & \multicolumn{3}{|c|}{ Age groups } & \multirow{2}{*}{$\begin{array}{c}\text { criterion } \\
\chi^{2}\end{array}$} & \multirow[b]{2}{*}{$p$-level } \\
\hline & Under 30 & $\begin{array}{c}\text { From 30 } \\
\text { to } 55(60)\end{array}$ & \begin{tabular}{|c|}
$55(60)$ \\
and older
\end{tabular} & & \\
\hline A desire to have healthy children & 47,3 & 17,3 & 2,2 & 241,719 & $<\mathbf{0 , 0 0 1}$ \\
\hline A need to feel oneself well & 46,3 & 43,0 & 51,4 & 8,062 & $=0,018$ \\
\hline A need to look well, to be liked & 41,6 & 30,9 & 28,4 & 15,669 & $<0,001$ \\
\hline A wish to increase (preserve) working capacities & 30,2 & 30,0 & 22,6 & 8,639 & $=0,013$ \\
\hline A wish to avoid visiting doctors & 25,8 & 27,6 & 28,4 & 0,589 & $=0,745$ \\
\hline A wish to avoid causing any inconvenience for a family & 21,5 & 26,9 & 47,9 & 76,327 & $<0,001$ \\
\hline A wish to have a long life & 19,1 & 17,8 & 23,7 & 6,252 & $=0,044$ \\
\hline $\begin{array}{l}\text { A desire to be a good example for one's children and } \\
\text { family }\end{array}$ & 16,1 & 18,4 & 20,8 & 2,734 & $=0,255$ \\
\hline A wish to achieve goals in life, work, or studies & 15,4 & 9,5 & 3,8 & 30,524 & $<0,001$ \\
\hline A fear to get ill & 14,8 & 18,2 & 24,8 & 13,168 & $=0,001$ \\
\hline Health deterioration or a disease & 6,7 & 13,7 & 26,4 & 57,834 & $<0,001$ \\
\hline
\end{tabular}

Note: * - data taken from "Physical health" sociological questioning performed by Vologda Scientific Center of the Russian Academy of Science, 2016. 


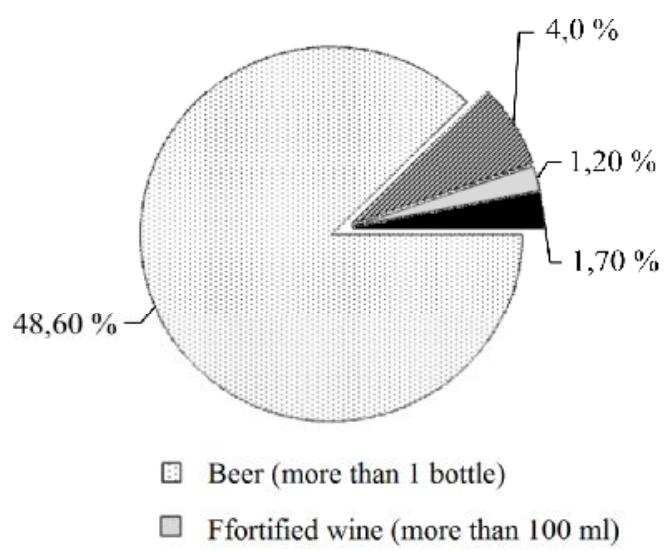

$a$

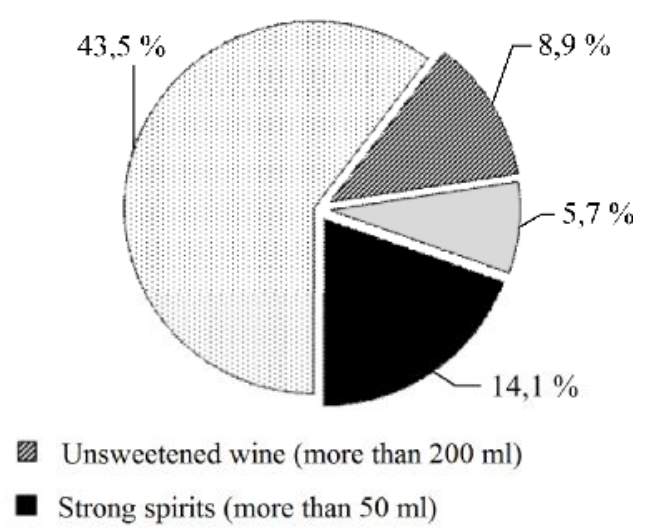

$b$

Figure 2. A structure of frequent alcohol consumption: $a$ - by young people (answers chosen are every day and every week end) (\% of all the respondents); $b$ - by people aged 30-55(60), answers chosen are every day and every week end (\% of all the respondents)

(data taken from "Physical health" sociological questioning performed by Vologda Scientific Center of the Russian Academy of Science, 2016)

improve their health, but this parameter was significantly higher among working population (aged $30-55(60))\left(36 \% ; \chi^{2}=\right.$ 36.322 at $\mathrm{p}<0.001)$. Therefore, $74 \%$ young people take these or those selfpreserving actions. However, a question arises immediately: how can these actions go together with self-destructing practices?

Bad habits. Approximately 65\% young people in Vologda region drink various alcohol in certain volumes. Beer is the most popular alcohol beverage among young people as $47 \%$ admit taking it every weekend against $43 \%$ among people aged 30-55(60) and 20\% among retired people. Strong spirits are usually taken during holidays: $46 \%$ adults and $38 \%$ young people drink more than $50 \mathrm{ml}$ of a strong spirit on holidays (Figure 2).

As per data obtained during the questioning in 2016, 36\% of young people smoked; smokers accounted for $40 \%$ among middle-aged people, and for $15 \%$ among retired people $\left(\chi^{2}=84.590\right.$ at $\mathrm{p}<0.001)$. Half of young smokers $(51 \%)$ would like to give this bad habit up.
Drug taking is rather rare in the region as a share of people who do it or have at least once tried drugs remains stably low (4\% in 2016). However, a specific weight of those young people who has at least once tried taking drugs is higher than the average level among population in the region $\left(6 \% ; \chi^{2}=21.526\right.$ at $\left.\mathrm{p}<0.001\right)$.

Physical activity. Young people in the region definitely go in for it. This population category do sports regularly on average two times more frequently than people from other age groups $\left(\chi^{2}=39.515\right.$ at $\mathrm{p}<0.001$ ): $13 \%$ do it every day; $20 \%$, at least 2-3 times a week. Such sports as jogging (almost 17\% do it regularly) and cycling $(27 \%)$ are the most popular among young people. However, morning exercises are not so popular among young people aged under 30 as only $10 \%$ of them do them. Young people frequently mention the following reasons for their low physical activity: lack of free time and poor selforganization (being lazy), 40\% answers for both reasons. But young people also state that higher incomes (47\% answers) and lower prices on sport inventory and season 
tickets to sport clubs $(37 \%)$ would help them to increase their physical activity.

Medical activity. Medical activity involves a person attending medical organizations and using resources provided by the public healthcare system. It is related to a frequency of applying for a medical health, regular use of medical services, and following medical recommendations [19]. Young people a bit less frequently attend a doctor bearing prevention in their minds (12\% against $16 \%$ among people older than 30). But as for the rest, their activity is similar to that of population from other age groups: $27 \%$ apply to a doctor in case of a disease or feeling bad, $22 \%$ had to have a medical examination before starting work, and $12 \%$ preferred self-treatment. $18 \%$ of young people have regular medical examinations.

Nutrition. Overall, most young people in Vologda believe their nutrition is adequate and rational (more than $80 \%$ an- swers). However, their nutrition includes carbohydrates in excessive quantities (bakery, cereals, and sweets). Frequent consumption of bakery and sweets is a threat to one's health as such food products contain free sugars in high quantities. Experts on nutrition and WHO nutritionists recommend to minimize free sugars consumption and make it not more than $10 \%$ of the overall consumed energy; to get additional healthy effect, they recommend to keep this parameter even lower than $5 \%$ of the overall consumed energy [20]. Young people, in terms of medical standards ${ }^{4}$, consume very few vegetables, and correspondingly, very little dietary fiber and vitamins. Meat, milk, eggs and fish are consumed in quantities which in general correspond to standards. Fast food is a bit more popular among young people than among other age groups as $39 \%$ consume it several times a week (Table 3 ) while only $28 \%$ of people

Table 3

Distribution of answers to the question: "How often do you consume the following products?:

(in \% of all respondents)

\begin{tabular}{|c|c|c|c|c|c|c|c|c|c|c|}
\hline Age & $\begin{array}{l}\text { Frequency of } \\
\text { consumption }\end{array}$ & Meat & Fish & Bakery & Eggs & $\begin{array}{l}\text { Dairy } \\
\text { products }\end{array}$ & \begin{tabular}{|c|} 
Fresh \\
vegetables
\end{tabular} & Fruit & Sweets & $\begin{array}{l}\text { Fast } \\
\text { food }\end{array}$ \\
\hline \multirow{3}{*}{ Under 30} & Daily & 28,5 & 3,4 & 72,1 & 21,5 & 63,4 & 58,1 & 45,3 & 41,9 & 3,7 \\
\hline & $\begin{array}{l}\text { Several times a } \\
\text { week }\end{array}$ & 68,4 & 85,7 & 25,2 & 74,4 & 34,9 & 42,0 & 52,0 & 49,3 & 38,9 \\
\hline & Rarely, never & 3,0 & 10,8 & 2,7 & 4,0 & 1,7 & 0,0 & 2,7 & 8,7 & 57,3 \\
\hline \multirow{3}{*}{$\begin{array}{l}30-55 \\
(60)\end{array}$} & Daily & 33,2 & 4,8 & 81,3 & 21,6 & 61,8 & 58,0 & 37,8 & 36,4 & 1,8 \\
\hline & $\begin{array}{l}\text { Several times a } \\
\text { week }\end{array}$ & 63,7 & 87,5 & 16,0 & 75,0 & 36,5 & 40,7 & 58,6 & 53,2 & 28,4 \\
\hline & Rarely, never & 3,1 & 7,6 & 2,7 & 3,4 & 1,7 & 1,3 & 3,6 & 10,5 & 69,8 \\
\hline \multirow{3}{*}{$\begin{array}{c}55(60) \\
\text { and older }\end{array}$} & Daily & 23,3 & 4,9 & 83,7 & 25,9 & 67,2 & 61,9 & 36,6 & 35,1 & 0,7 \\
\hline & $\begin{array}{l}\text { Several times a } \\
\text { week }\end{array}$ & 73,3 & 86,8 & 15,1 & 71,4 & 30,6 & 38,0 & 58,2 & 54,1 & 9,4 \\
\hline & Rarely, never & 3,3 & 8,3 & 1,1 & 2,7 & 2,2 & 0,2 & 5,1 & 10,7 & 89,9 \\
\hline \multicolumn{2}{|c|}{ criterion $\chi^{2}$} & 13,252 & 3,827 & 19,116 & 4,150 & 4,594 & 9,174 & 8,747 & 4,125 & 106,397 \\
\hline \multicolumn{2}{|l|}{$p$ - level } & 0,010 & 0,430 & 0,001 & 0,386 & 0,332 & 0,057 & 0,068 & 0,389 & $<0,001$ \\
\hline
\end{tabular}

Note: * data taken from "Physical health" sociological questioning performed by Vologda Scientific Center of the Russian Academy of Science, 2016.

${ }^{4}$ According to WHO recommendations, fruits and vegetables should be eaten daily, while their daily intake should be at least $400 \mathrm{~g}$ (5 servings). Potatoes, sweet potatoes, tapeworms and other starchy roots are not counted [21]. 
aged 30-55(60) and 9\% of retired people do it with the same frequency.

To keep their nutrition rational, young people most frequently try not to overeat and to consume qualitative food products ( $40 \%$ answers in both cases), and it is quite the same for people from other age groups. $19 \%$ of young respondents were on a diet because they wanted to control their body weight and not because their doctors told them so; it confirms that a desire to look well prevails among other motives for self-preserving behavior in this age group.

Proneness to stress and ways to overcome it. Mental health is an integral and most significant component of the overall human health. A lot of experts believe that people nowadays face stresses more and more frequently and it has adverse effects on their health [22]. As per data obtained by Vologda Scientific Center of the Russian Academy of Sciences, 82\% of people in Vologda mention being in a stressful situation; $16 \%$ are under stress regularly (every day or twice a week). $78 \%$ of young people have experienced it at least once, $17 \%$ are under regular stress. Physical exercises, rest, hobby, or an expert's help are considered to be the most correct and harmless ways to overcome and prevent stresses. Our monitoring data prove there are both "healthy" $\left(^{2}=15.596\right.$ at $\mathrm{p}<0.001)$ and destructive ways to overcome stress among young people $\left(^{2}=\right.$ 32.715 at $\mathrm{p}<0.001)$. The former include walking $(37 \%)$, doing a hobby $(23 \%)$, or physical exercises (15\%). But being under a stress, young people often resort to the quickest, most available and not always useful means. Thus, for example, when they want to "calm down and come to their senses" they use such destructive measures as "eating a stress away" (28\%), smoking $(20 \%)$, and alcohol intake (6\%). And stress becomes one of key reasons for abuse. Besides, $27 \%$ of young people do nothing to overcome stresses due to various reasons, including their own unwillingness to do something (13\%) and lack of knowledge how to fight stresses (14\%).

Health-preserving practices. Giving up smoking is the most widely spread health-preserving practice both among young people (46\% respondents) and population in general. It can be to a great extent explained by a large-scale antitobacco program now being implemented in the RF, including stricter anti-tobacco legislation. Thus, the RF Federal Law No. 15-FL "On protecting citizens' health from impacts exerted by tobacco smoke and consequences of tobacco consumption" ${ }^{5}$ came into force on June 01, 2013; this law bans smoking completely in all closed public places, and it also prohibits tobacco advertising, sales promotions for cigarettes, smoking by under-age citizens, and it imposes certain limits on explicit smoking in TV programs and movies as well as selling cigarettes and tobacco-containing goods.

Besides there are other popular actions such as visiting saunas, moderate alcohol intake, and use of water-purifying appliances. Young people do active sports and tempering more often than people from other age groups $\left(21 \% ;^{2}=10.183\right.$ at $\mathrm{p}=$ 0.006).

\footnotetext{
${ }^{5}$ Ob okhrane zdorov'ya grazhdan ot vozdeistviya okruzhayushchego tabachnogo dyma i posledstvii potrebleniya tabaka: Federal'nyi zakon № 15-FZ ot 23 fevralya 2013 g. [On protecting citizens' health from impacts exerted by tobacco smoke and consequences of tobacco consumption: RF Federal Law No. 15-FL]. Garant: informatsionnopravovoi portal. Available at: http://base.garant.ru/70321478/\#text (27.03.2018).
} 
Conclusion. To sum up, we should note that young people's behavior in respect of their health has certain peculiarities in comparison with people from other age groups. Traditionally young people who haven't yet accumulated "health problems" assess their health as being quite good and feel themselves responsible for it. Their values as regards their health preservation fit their age: they wish to have healthy children, they want to feel themselves well to pursue active social and working life; they also have aesthetic motives (a desire to look good and to be fit via keeping a diet). Young people visit a doctor less frequently, but they do sports more often than people from other age groups. But still there are certain self-destructive practices in their lives: they consume low alcohol drinks (beer) more frequently than people from other age groups, they also eat fast food and smoke more often, and they are not strong-willed enough to give this bad habit up even when they want to. And it is their desire to overcome stresses that makes young people smoke, drink alcohol, or eat unhealthy food.

A positive experience of selfpreserving practices among people from this population group should be applied in motivating them to pursue a healthy lifestyle; such practices should become a part of their life and remain in it at older ages, and this successful experience should be transferred to the following generations. There are several tools to achieve it; we can mention such relevant and up-to-date ones as creation of a socially approved and "fashionable" image of a healthy person in mass media, the Internet [23] and art works; working out health improvement programs at educational establishments and at workplaces; making medical services aimed at prevention more available as it makes for early detection of diseases.

Funding. Our research was not granted any sponsors' support.

A conflict of interests. The authors state there is no conflict of interests

\section{References}

1. Chislennost' naseleniya Rossiiskoi Federatsii po polu i vozrastu [The RF population as per sex and age]. Federal'naya sluzhba gosudarstvennoi statistiki. Available at: http: //www.gks.ru/wps/wcm/connect/rosstat_main/rosstat/ru/statistics/publications/catalog/doc 1140095700094 (14.03.2018) (in Russian).

2. Demografiya: Demograficheskii prognoz do 2035 goda [Demography: Demographic forecast up to 2035]. Federal'naya sluzhba gosudarstvennoi statistiki. Available at: http: //www.gks.ru/wps/wcm/connect/rosstat_main/rosstat/ru/statistics/population/demography/\# (14.03.2018) (in Russian).

3. Molodezh' sovremennoi Rossii - klyuchevoi resurs modernizatsii: monografiya [Young people of modern Russia are the key resource for modernization: monograph]. In: A.A. Shabunova ed. Vologda, ISERT RAN Publ., 2013, 148 p. (in Russian).

4. Rimashevskaya N.M. Social'naya politika sberezheniya naroda: radikal'noe izmenenie negativnogo trenda zdorov'ya rossijskogo naseleniya [Social policy of nation preservation: drastic change of negative health trend of the Russian population]. Ekonomicheskie $i$ sotsial'nye peremeny: fakty, tendentsii, prognoz, 2010, no. 4 (12), pp. 48-61 (in Russian).

5. Deti reform [Children of reforms]. In: N.M. Rimashevskaya ed. Moscow, Institut ekonomicheskikh strategii Publ., 2011, 304 p. (in Russian). 
6. Chislo umershih po prichinam smerti, po polu i vozrastu po Vologodskoj oblasti v 2006 godu: statisticheskii sbornik [Death cases in Vologda regions in 2006 as per causes, sex, and age: statistic data collection]. Vologda, Vologdastat Publ., 2007, 150 p. (in Russian).

7. Chislo umershih po prichinam smerti, po polu i vozrastu po Vologodskoj oblasti v 2015 godu: statisticheskii sbornik [Death cases in Vologda regions in 2015 as per causes, sex, and age: statistic data collection]. Vologda, Vologdastat Publ., 2016, 300 p. (in Russian).

8. Gardner J.W., Sanborn J.S. Years of potential life lost (YPLL) - what does it measure? Epidemiology, 1990, vol. 1, no. 4, pp. 322-329.

9. Novgorodova A.V. Poteryannye gody zhizni - indikator zdorov'ya naseleniya [Years of life lost as the indicator of population health]. Narodonaselenie, 2015, no. 2, pp. 74-86 (in Russian).

10. Lisicyn Yu.P. Obshchestvennoe zdorov'e i zdravoohranenie [Public health and health care]. Moscow, GEHOTAR-MED Publ., 2002, 520 p. (in Russian).

11. Global status report on noncommunicable diseases 2014. Geneva, World Health Organization Publ., 2014, 302 p.

12. Sommer I., Griebler U., Mahlknecht P. [et al.]. Socioeconomic inequalities in noncommunicable diseases and their risk factors: an overview of systematic reviews. BMC Public Health, 2015, vol. $15 . \quad$ Available at: https: //bmcpublichealth.biomedcentral.com/articles/10.1186/s12889-015-2227-y. DOI: 10.1186/s12889-015-2227-y (07.05.2018).

13. Wu F., Guo Y., Chatterji S., Zheng Ya. [et al.]. Common risk factors for chronic noncommunicable diseases among older adults in China, Ghana, Mexico, India, Russia and South Africa: the study on global AGEing and adult health (SAGE) wave 1. BMC Public Health, 2015, vol. 15. Available at: https://bmcpublichealth.biomedcentral.com/articles/10.1186/s12889015-1407-0. DOI: 10.1186/s12889-015-1407-0 (07.05.2018).

14. Nakitanda A., Shvireb G., Armstrong T. Rastushchee bremya neinfekcionnyh zabolevanij i rol' fizicheskoj aktivnosti [The increasing burden of non communicable diseases and the role of physical activity]. Profilakticheskaya medicina, 2014, no 1, pp. 12-17 (in Russian).

15. Rezapkina V.G. Samorazrushitel'noe povedenie: prichiny i profilaktika [Selfdestructing behavior: causes and prevention]. Akademicheskij Vestnik Akademii social'nogo upravleniya, 2017, no. 2 (24), pp. 18-24 (in Russian).

16. Shabunova A.A., Korolenko A.V. Sovremennaya model' zdorovogo obraza zhizni: mesto profilaktiki $\mathrm{v}$ povsednevnyh praktikah naseleniya regiona [Contemporary model of healthy lifestyle: prophylaxis in the daily routines of the region's population]. Demograficheskij potencial stran EAEHS: sbornik statei VIII Ural'skogo demograficheskogo foruma. Ekaterinburg, Institut ehkonomiki UrO RAN Publ., 2017, pp. 489-497 (in Russian).

17. Korchagina P.S., Shabunova A.A. Cennostnye ustanovki i povedencheskie praktiki kak znachimye faktory samosohranitel'nogo povedeniya molodezhi [Value orientations and behavioral practices as significant factors in self-preservation behavior]. Social'noe prostranstvo, 2015, no. 1. Available at: http://sa.vscc.ac.ru/article/1641 (20.03.2018) (in Russian).

18. Shabunova A.A. Zdorov'e naseleniya v Rossii: sostoyanie i dinamika [Public health in Russia: state and dynamics]. Vologda, ISEHRT RAN Publ., 2010, 408 p. (in Russian).

19. Miller M.A. Samosohranitel'noe povedenie naseleniya kak ehlement demograficheskogo razvitiya [Self-preservation behavior of the population as an element of demographic 
development]. Aktual'nye voprosy ehkonomicheskih nauk, 2009, no. 8-1, pp. 167-171 (in Russian).

20. Sugars intake for adults and children. Geneva, World Health Organization Publ., 2015, $49 \mathrm{p}$.

21. Diet, nutrition and the prevention of chronic diseases: report of a Joint WHO/FAO Expert Consultation. Geneva, World Health Organization Publ., 2003, 149 p.

22. Buhtiyarov I.V., Rubcov M.Yu., Kostenko N.A. Sovremennye psihologicheskie faktory riska i proyavleniya professional'nogo stressa [Modern psychological risk factors and manife stations of the professional stress]. Izvestiya Samarskogo nauchnogo tsentra Rossiiskoi akademii nauk, 2014, vol. 16, no. 5-2, pp. 773-775 (in Russian).

23. Gruzdeva M.A. Instrumenty formirovaniya samosohranitel'nyh praktik naseleniya: social'nye seti i blogosfera [Tools for shaping people's self-preservation practices: social networks and the blogosphere]. Social'noe prostranstvo, 2017, no. 4. Available at: http://sa.vscc.ac.ru/article/2378 (27.03.2018).

Gruzdeva M.A., Korolenko A.V. Behavioral factors which can influence preservation of young people's health. Health risk Analysis, 2018, no. 1, pp. 41-51. DOI: 10.21668/health.risk/2018.2.05.eng

Received: 04.05.2018

Accepted: 01.06.2018

Published: 30.06 .2018 